\title{
ENDOSCOPIC EXAMINATION OF THE OLFACTORY MUCOUS MEMBRANE
}

HARUHIRO NAGANO, M.D.

Department of Oto-Rhino-Laryngology, School of Medicine, Showa University, Tokyo.

(Director: M. Okamoto, M.D.)

For diagnosis and treatment of dysosmia, a useful technique has been developed in our clinic, that is, a macroscopic observation of the olfactory mucous membrane utilizing an endoscope. For this study, an Olympus Selfoscope SES-1711D was used as an endoscope with a diameter of $1.7 \mathrm{~mm}$, and it was inserted into the rima olfactoria under non-anesthetic condition.

Thirty-one normal cases and 64 cases of dysosmia were employed, as the subjects.

The normal olfactory mucous membrane was well lubricated as that of the respiratory region, but a slight niche was found on its surface.

The olfactory mucous membrane was light brownish-yellow.

The boundary area of the olfactory mucous membrane was gradually transmuted into the respiratory region

The olfactory mucous membrane of dysosmia was divided into the following 4 types in this observation.

(i) Swelling type: The olfactory mucous membrane was coated with increased secretion, looked rather pale, and most of the niches were decreased or disappeared, 22 cases. belonged to this type. (ii) Secretory type: Even niches and the color of the olfactory mucous membrane were similar to normal cases, but the secretion was increased. This is observed in 10 cases.

(iii) No change type: No abnormalities were found on the olfactory mucous membrane in 17 cases.

(iv) Dry type: Secretion of the olfactory mucous membrane appeared to be reduced or dried, and the color was rather brownish. This is shown in 9 cases.

The dry type was further divided into 2 types.

(a) Atrohic type: The niche of the olfactory mucous membrane became deeper; 6 cases.

(b) Hypertrophic type: The niche of the olfactory mucous membrane disappeared or became shallow; 3 cases.

Further, in 6 cases, different observations were obtained in both sides of the nose

In these, there were no pathology in one side, and in another side, 5 cases were the swelling type and 1 case was the secretory type.

In most cases of the swelling type and secretory type, the olfactory mucous membrane returned normal, but the cases in the no change type and the dry typf got no remarkable improvement by the treatment. By this method, the olfactory mucous membrane of dysosmic patients was able to be observed directly and the effect of the treatment was easily traced, therefore, more exact diagnosis, treatment, and accurate prognosis could be performed. 
A $80-0241-32533$

\section{嗅粘膜の内視鏡所見に関する研究}

炤和大学医学部耳鼻咽喉科学教室 (主任: 阔本途也教授)

特別研究生 長 野 治 啓

\section{緒言}

嗅覚に関する研究は他の感觉に比較して扝く机ていた が, 次第にその重要性が認識され, 最近では多くの研究 者によってさかんに研究が行わ饥るようになってきた。 昭和大学取鼻咽喉科学教室では人間の傻覚, ことにその 障害者の診断・治療については種々の研究を行ってき た。

著者は今回内視鏡により嗅覚正常者㧍よび障害者の嗅 粘膜（主として前部領域の天蓋部を中心に）を肉眼的に 観察することに成功し, 嗅覚障害者の診断・治療に有効 な知見をえたので報告する.

\section{研究方法}

(1) 内視 鏡

内視鏡はオリンパス製セルフォスコープ (MODEL, SES-1711D）をもちいた（写真 1，図1）。これは関節 鏡として開発されたものである. 本器は細い針状の光学

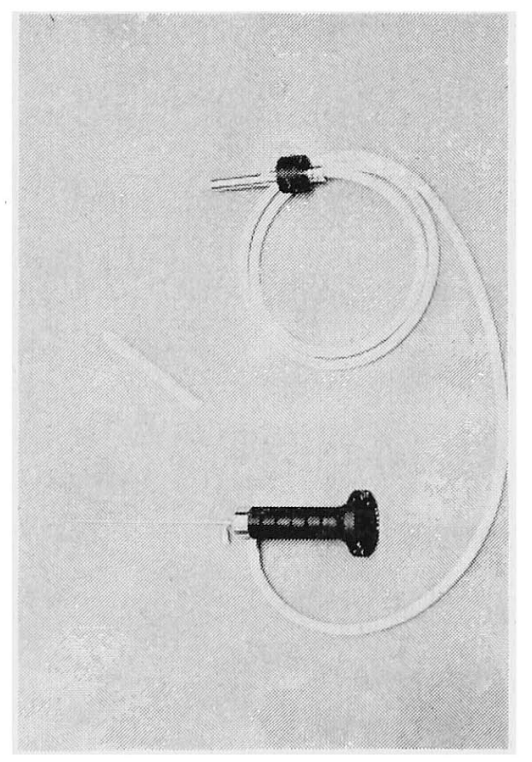

写真 1 セルフォスコープ
視針と接眼レンズ部分よりなりたっている. 光学視針は 直径 $1.0 \mathrm{~mm}$ のセルフォックレンズと, これを層状にと りまく照明用ライトガイド（厚さ $0.25 \mathrm{~mm}$ ）およびステ ンレスチューブ（厚さ $0.1 \mathrm{~mm}$ ) からなり，その外径 は $1.7 \mathrm{~mm}$ ，長さは $120 \mathrm{~mm}$ である。

セルフォックレンズは特殊な組成のガラスロッドにイ オン交舆の処置を加えることにより，屈折率が中心軸で 最大で，中心軸からはなれるにしたがって徐々に放物線 状に小さくなるようにつくられたものである。このため 周辺にむから光線は常に中心軸の方に引きもどされ，正 弦曲線をえがきながら進むため，伝送による光エネルギ 一の損失は非常に少ない，また中心軸にそって正弦曲線 をえがきながら進む光線は一定の間隔をもって倒位像, 正位像上峦互に像を結ぶため, セルフォック ガラス口 ッドの適当な長さのものはレンズとしての機能をもって いる。 セルフォックレンズはまた非常に小さい焦点距離 (1 $\mathrm{mm})$ と最大の焦点深度 $(1 \mathrm{~mm}$ ○) をもっているた め，その先端にきわめて近接した物体とある距離にある 物体上在同時に明視でき，更にこれ艺接眼レンズにより 抎大してみることができる1

(2) 光 源

オリンパス製万能高輝度光源装置, CLX をもちいた (写真 2).

(3) 真撮影

カメラはセルフォスコープに付属している自動フィル 么巻き上げ装置付オリンパス OM-1 をもちいた。摄影 は光源の光量最大にし, カメラレンズの焦点距離を無 限大にし、シボリを開放し、ジャッター スピードを1 $1 / 8$ 秒にして撮影した。フィルムはコダック EH, ASA 160 をもちいた。現像は 2 倍增感にて行った。

(4) 娭查手技

被検者を耳鼻科診察台に坐らせ，頭部を後屈する体位 在とらせた。

内視鏡の㧴人は無麻醖下にて行のた。 


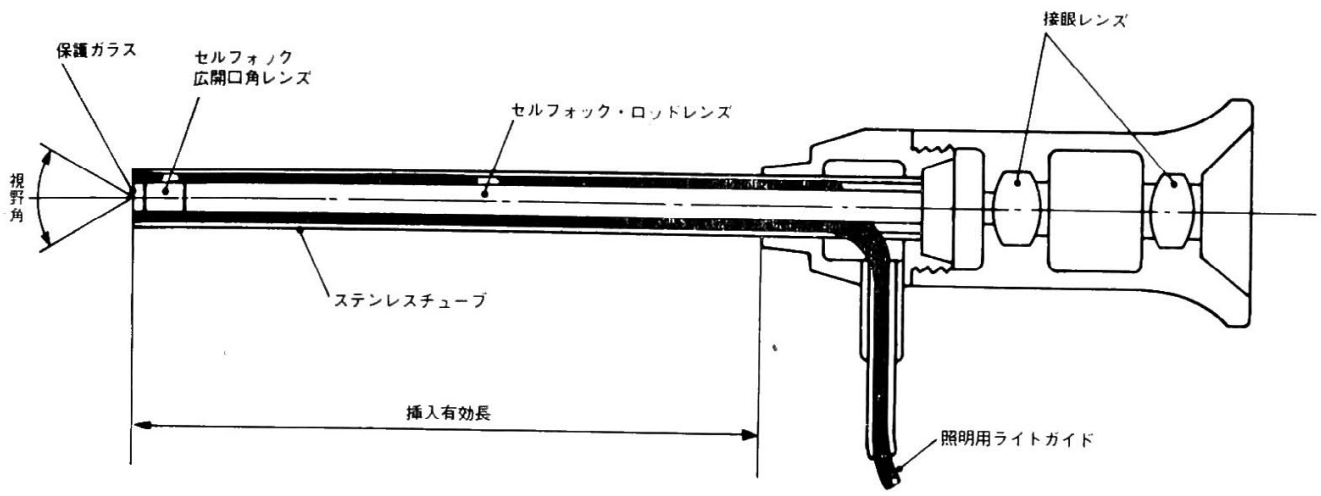

光学視針の最小径 : $1.7 \mathrm{~mm}$

光学視針の有効長 : $45 \sim 120 \mathrm{~mm}$

視野角

$: 55^{\circ}$

焦点深度

$: 1.0 \mathrm{~mm} \sim \infty$

外套管の最小外径 : $2.0 \mathrm{~mm}$

図 1 七ルフォスコープの構造

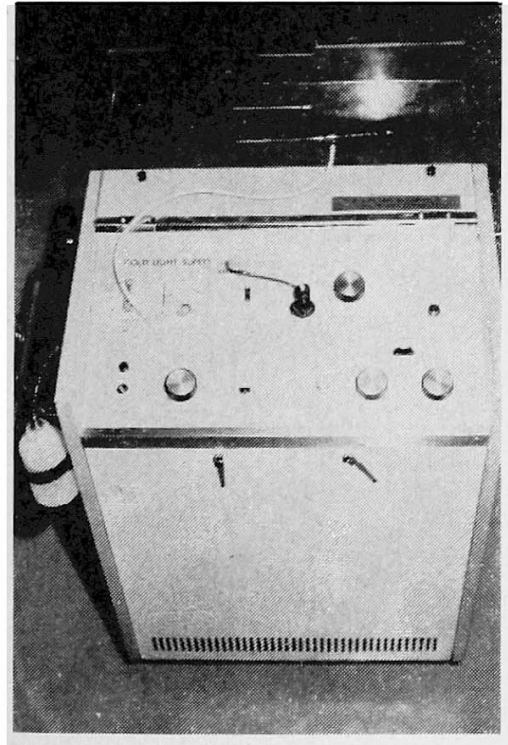

写真 2 光源装置 CLX

挿入の際鼻甲介, 鼻中隔にできるだけ子れないように するため，その手技を 2 段階に分けた，第 1 段階では前 鼻腔加ら挿入した内視鏡を鼻溝部にそってその先端を鼻 腔天蓋部まで進め, 第 2 段階では内視鏡の先端を鼻腔天 蓋部にそってす心ららせるらにして後方一進め, 嗅粘膜 部まで達せしめた。この第 2 段階ではどうしても鼻甲
介，鼻中隔に軽く子抽るため，この操作を可及的にすみ やかに行った。このよ5にして光学視針の先端を嗅粘膜 部の前部領域に到達せしめた。 また插入の際，できるだ け内視鏡の先端に分泌物がつかないように注意した。

このような方法をとれば両側鼻腔の嗅粘膜の前部, 主 として天蓋部を中心に観察することができる．観察中は 内視鏡を左手指にて鼻入口部で軽く保持し，くしゃみ， 疼痛等の際すみやかに抜去できるよら対処した。

\section{研 究 成 績}

[A]嗅覚正常者の嗅粘膜の内視鏡所見

嗅覚検査 ${ }^{23}$ ) (嗅力検査およびアリナミンによる静脈 性嗅覚検査）が正常で，鼻・副鼻腔に異常を認めないも の31例（17才〜33才）について内視鏡検査を行った。

嗅営正常者の嗅粘膜は写真 3 に示すよ5な所見であの た。すなわち呼吸部粘膜と同様に湿潤性にとんでいた が，その表面には軽度の小さな叫が多数みられ, 色調 は淡い黄褐色を呈していた。また呼吸部との境界は判然 とせず,次第に呼吸部粘膜に移行しているようにみえた。

〔B]嗅覚障害者の嗅粘膜の内視鏡所見

昭和49年 6 月から50年 2 月までの間に, 嗅覚脱失を訴 えて昭和大学病院耳鼻咽喉科嗅覚外来を受診した嗅覚障 害者71例について内視鏡検査を行った，両側鼻腔の嗅粘 膜の観察が可能であった症例数は64例（90.9\%）であっ た。 


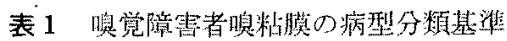

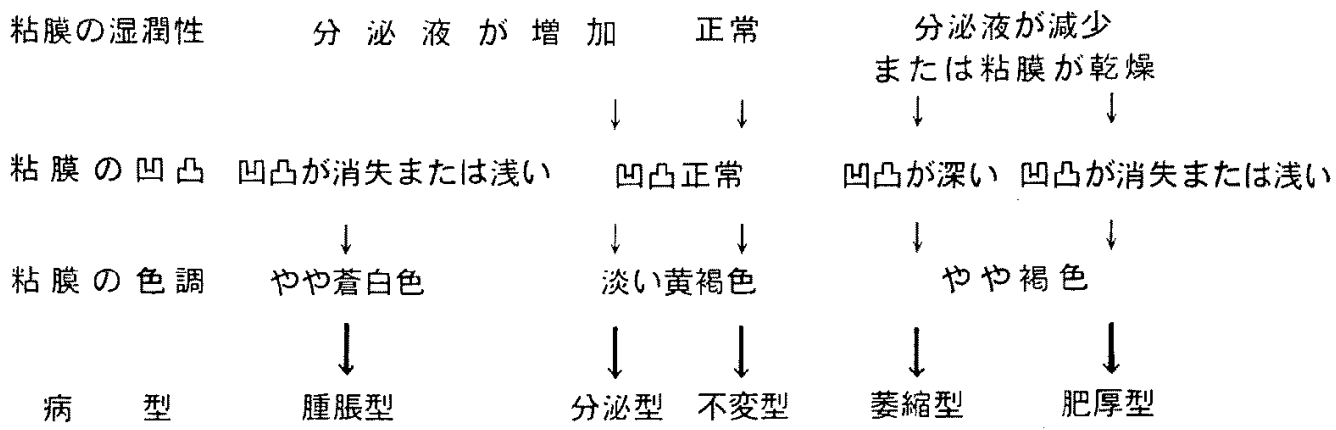

乾燥型

更にこれらの症例の治療経過圭内視鏡で追い，臭粘膜 所見の変化について檢討した，治療には大テロイド点鼻 療法 $(0.1 \%$ \%キサメサゾン液または0.1\%ぶタメザン

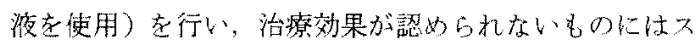

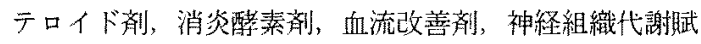
活剛，抗アレルギー剂等の内服を併用した。

(1) 内視鏡的所見

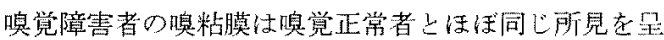

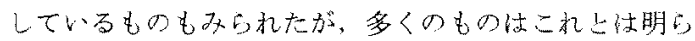
かにことなった所見を示していた。

背粘謨の湿潤性については，(1)正常嗅粘膜と同程度の 湿潤性在有子るもの，(2)分必液加增加しているもの，(3) 分泌液が減少あるいは乾燥しているものの3群に大别さ れた。

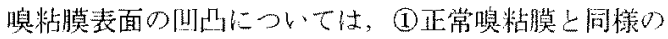
むの，(2)山几が消失あるい浅くなっているもの，(3) 凸が哚くなっているものの3群に大別された。

覑粘膜の色調については, (1)正常の色調のもの（2)や や荅四色のもの, (3)や褐色の更のの3群に大别され た。

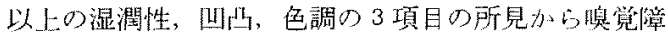
者者の嗅粘慕を表1の如く分類した。

(i) 腫脹型（军真 4)：搝粘膜の分泌液の增加がみり

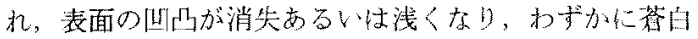
色袁旺しているの，

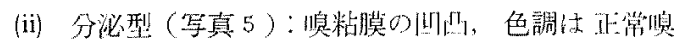
粘膜とほ上んど同じであるが分泌液が增加しているも D.

(iii) 不変型：正常嗅粘膜上ほほ同棅の所見 0 し。

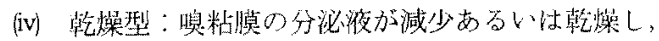

表 2 嗅営障害者瑱粘膜の病型分類結果

$\begin{array}{lll}\text { 腫 脹 型 } & 22 \text { 例 } \\ \text { 分 泌 型 } & 10 \text { 例 } \\ \text { 不 変 型 } & 17 \text { 例 }\end{array}$

乾 燥 型 $\quad 9$ 例 $\begin{cases}(\mathrm{a}) \text { 萎縮型 } & 6 \text { 例 } \\ (\mathrm{b}) \text { 肥厚型 } & 3 \text { 例 }\end{cases}$

病型が左右で 6例

罢なるむの

\section{計 64 例}

色調は正常のものにくらふやや褐色になっているもの， この型は更に粘膜表面の凹几から次の2型分けた。

(a) 萎縮型（写真6）: 四四が深くなっているむの.

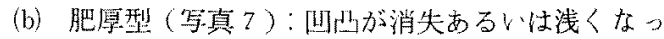
ているもの.

この分類にしたがって，著者の経験した搝覚障害者の 嗅粘膜を分頪すると（表2），腫脹型は22例，分泌型は 10例, 不変型は17例, 乾燥型は9例（蒌縮型は6例, 肥 厚型は3例)しなった。

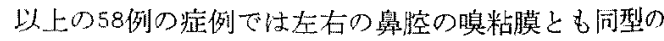
所見を禾していたが，残りの6例で左右の鼻腔で嗔粘 膜の所見がこ上なっでた。これらの6例は片側はすが て不変型で，他側が腄脹型であったものが 5 例，分泌型 であったものが例であった。

(2) 治療による嗅粘漠の爱化

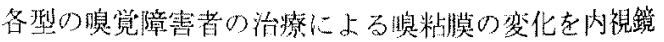
にて絸察した。

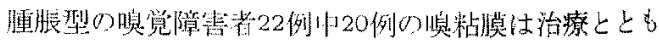


に次第に分泌液は減少し，表面の山凹，色調もほ伍正常

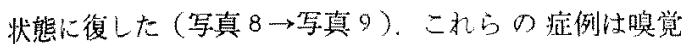
换查にても嗅覚が完全に回復したものが13例双られた。

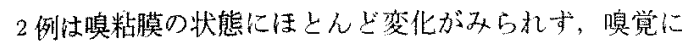
し変化がみら机なかった。

分速型の嗅覚障害者の嗅粘膜は10例全例上も治瘵によ

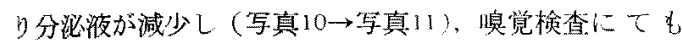
7 例は嗅鸴が完全に回復した。

不変型の嗅喾障害者12例は治療してb嘎粘偾に变化は 認められなかったが，Zのうち嗅党が完全に回復したも のが 5 例あった

乾燥型（萎樎型および肥厚型）の嗅觉障害者・例は治 㙩しても㖵粘膜に変化はみられ寸゙，嗅覚も完全に回復し たものはなかった。萎縮㤠の唤党障害者6例のなかに， わずかに喂覚が回復したものが 2 例みられたが，内視踥 では嚊粘膜に特に変化を認めることはできなかった。

\section{考按}

(1) 内視鏡について

著者は過去に関節鏡として用いられていだ彩いダラ久 ファイバースコープをもちい㖵裂の観察をしたが，その 器械は管を細くすればファイバ一の数に制限があり，解 像力に限度があり，太くす机洋解像力は增すが嗅裂心雨 入することが困難であった。しかしセルフォスコープを しちいると管が細くなり㢹い部分にまで舫入することが でき，嗅裂深部まで䘽察することができるのみならず解

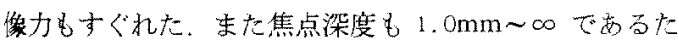
か，1度に広範用の部分を明瞭にみることができた。 のためセルフォスコープ责使用す机ば内視鏡の雨入が容

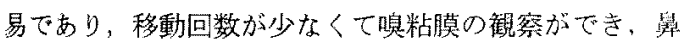
粘膜のような非常に鋭敏な部の検査にはきわめて有利て ある。

短焦点であるためコマ歪み长心配したが，観察に支陵 をきたすほどのコマ歪みはみられなかった。

(2) 光激拈よび写真撮影について

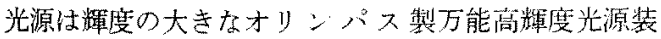
置，CLX をもちいた，些に観察するだけであれ代これ よりも輝度の小さい光源をもちいてもよいが，写真撮影 を行うには CLXでなけ机ば光量が不十分であった。 加し CLX の光量を最大にして撮影し，增感涀像して も, シャッター スピードが秒より短かくては光量が 不十分であった，光量不足はライトガイドのグラスフン イバーの数が少ないためやむ学えないものと教える。 ヤッター・スピードが1/8秒より長ければ光星は啮足でき
るが，手ぶれがいらら゙るしく，写真が非常に不鮮明上な

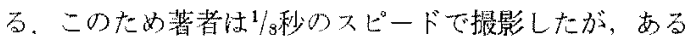
程度の手ぶれがみられ，肉腿でみる上らな明膫な写真仗 とることがでさなかーな。

(3) 検查手技につけて

内視鏡の插入に際して在，なる心゙く嗅粘漠の状態を变 化しないままで微察したいため，林䣷辈等のスプレを行 わなかった。このため，著者が挿入に不なれであった填 はくしやみ、疼痛，分泌物の增加等になや它され，挿入 に困難をきたす例が多かった。このよらな障害を少しで も軽減子るためには䁷甲介，舅中隔にできるだけ子れな いよらに注意して内視鏡を塖入することが非常に大切で ある上考えた。このため末才゙内視鏡老前舅腔上り嵊入

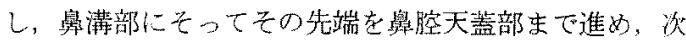
に先端をす心゙らせるよ5にして後力八進めた。このち法 で行うと被検者にほとんど苦痛を与えることなく内視鏡 を嗔粘膜部まで挿入することができた。

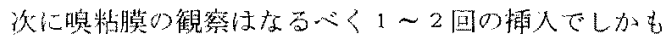
短時間に行らこ上が必要である。熟練した検者が行えば 被検者に苦痛をほとんど与えないが、法ったく無刺激上

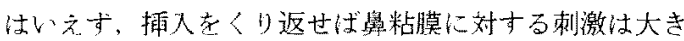
く嗅粘膜の状態が变化する可能性がある，ゆえに観察絬 果の判定には留意す心゙きでる。 また写真撮影も自動つ イルム巻き上げ装置付のカメラを用い、速やかにしかも 䓡時間に行号必要がある。

(4) 搝覚正常者の嗅粘膜所見につマて

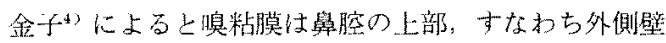
では上鼻甲介，上鼻道から中學甲介にわたり，内側壁で はこれに相当する鼻中隔の同高部に存在し，その面積法

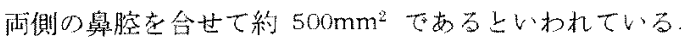

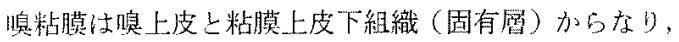

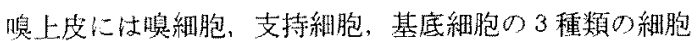
があり，更に粘膜上皮下組織には多数の嗔腺（ボウマン 腺)がみら机る。

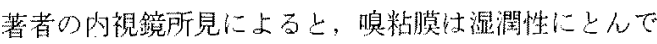

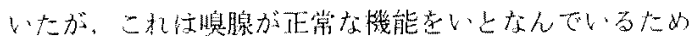

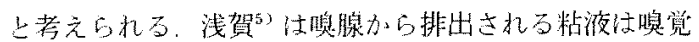

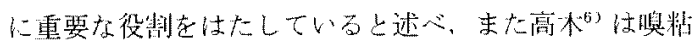

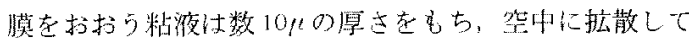

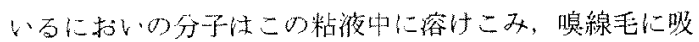
着する上述ふている。したが，て搝粘膜が湿潤性である

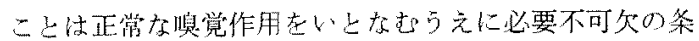
作七者える。 
更に，著者の内視鏡所見で任嗅粘膜袁面に整度の小さ な山山が多数認められている。これについては内視鏡で

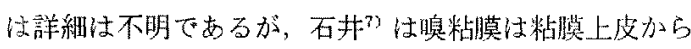
骨までの結合織がうすいと述心゙ているので，䁷腔天盖，

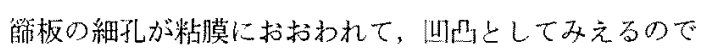
はないかと思考している。

色調についてはすでにいるいるな報告があり，金子か

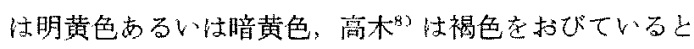
述ふてている，石升9 は呼吸部粘膜上肉眼的に区別できな いとしている，著者の内視鏡所見では嗅粘膜は呼吸部粘 膜に比較してわずかに淡い黄褐色を呈している程度で亦 って，一般にいわれているよらな明瞭な呼吸部粘膜との 色調の差は認められなかった。

粘膜の凹凸，色調加らは嗅粘膜之呼吸部粘膜之の境界 は判然としなかった。すなわち雨粘膜の移行ははっきり とした境界があるのではなく，䁚粘膜の中心部では密で あった嗅細胞の分布が周辺では次第に粗になっていき， やがて完全に呼吸部粘膜になるのではないかと推測して いる. 石井 ${ }^{9}$ は嗅細胞の正確な㹡がりについて瑱粘膜 の連続切片の計測による reconstruction が必要である と述べているが、これは現在のところまだ行われていな $\cdots$

以上により著者は適度の湿潤性と凹凸をもち，淡い黄 裸色を呈している嗅粘膜を正常嗔粘膜と考えた。

（5）唤觉障害者の検査手技について

嗅裂，嗅粘膜の状態の診断法としては，前为鏡検查の 他には井沢 ${ }^{00}$ の嗅裂部計測, 嗅裂部造影, 飯泉 ${ }^{11}$ の嗅裂 部断層撮影等のX線学的方法がある。著者汁内視鏡によ る嗅粘膜の観察を行った。

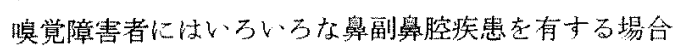
が多く，嗅裂の変化む多いので，内視鏡の插入および嗅 粘膜の観察が難かしいるのが多いのではないかと予想し ていた。しかし鼻腔上部にいちぢるしい鼻中隔彎曲，菑 甲介肥大ホポリープがあった症例以外はすべて内視鏡の 㨂入，観察をすることができた。これは当初の予想より わはるかに良い結果であった。

観察した嗅粘膜は主上して前部隤域の天蓋部のもので あり，嗅粘膜全体をみたわけではないしたがって観察 できなかった部分については不明であるがこ机性内䙺 鏡の性誓，䘽察手技から考えるとやむ在えないしか し, この領域の観察からでも, 嗅粘膜全体の病変を推测 できるもの上思考している。

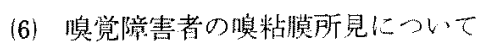

著者が行った内視鏡検査によると，嗅覚障害を訴える ものには嘎粘膜に異常をきたしているものが多数認めら れた。

嗅粘膜の湿润性の変化については正常, 分泌液の增 加，分泌液の減少あるいは乾燥の3型に分けられた，分 泌液の增加は嗅腺の機能六進，嗅粘膜毛細血管の透過性 允進等が存在しているもの上推測される．逆に分泌液の 隇少あるいは軘燥は嗅腺の機能低下, 消失が存在するも の上推測できる。

䁚粘膜表面の凹凸の変化では正常, 凹几が消失あるい は浅くなったもの，凹凹が媣くなったものの3型に分け られた、凹凸が消失あるいは浅くなっているのは鼻腔天 蓋, 節板の細孔が嗅粘膜の腫脹, 肥厚により不鮮明にな ったもの上推測され，凹凸が深くなっているのは嗅粘膜 の萎縮により細孔の凹凹がかえって明膫になったものと 推測される。

嗅粘膜の色調の変化については正常, やや荟白色, や や褐色の3型に分けられたが，このような色調の変化 は嗅粘膜の性状，湿潤性の変化によるものと考えられ る。

嗅粘膜の湿潤性，凹凸，色調の相互間には一定の関連 性がみられた（表 1)。このことから嗅覚障害者の嗔粘

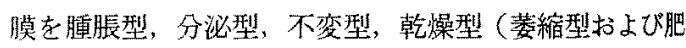
厚型)の各型に分けるのが妥当と考えた。

腫脹型の嗅粘膜は表面の凹凸が消失あるいは浅くな り，やや嚄白色であるが，これは嗅粘膜に炎症が存在す るため上考えられる。このため本型は嗅腺の分泌機能が 充進し，分泌液も増加しているもの上思若している．

分泌型溴粘膜の凹凸，色調には変化がなく分泌液の み増加しているが，これは何らかの原因により嗅腺の機 能僬が起っている状態と考える。

不変型の嗅粘膜注啰覚正常者のもの上同様の所見であ り，内視鏡からは嗅粘膜の病変をみいだすことはできな かった。この型に属するものは主として搝紐胞あるい忧 䇱系以後に何占かの障害が存在するものと推測せざるを えない。

乾燥型は嗅粘膜の分泌液が減少あるいは乾燥して㧍 り，これは嗅腺の分泌機能低下あるいは消失が起ってい るものと考える。乾學型の搝粘膜は表面の凹凹の状態に より姿縮型，肥厚型の 2 型に分けた。

Morrison ${ }^{12)}$ は後部篩骨蜂巣に病変があると嗅粘膜に 炎症をきたし，末杪神経の萎縮，嗅粘膜の退行変性を起 す上述べて扝り，また高橋13》は嗅裂部粘膜の肥厚は，鼻 


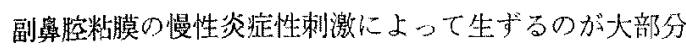
であると述心ててる。

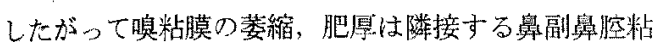
膜の炎症によって起ることがもっ上も多い上考えられ る。また炎症性刺激の他にも加令 ${ }^{14}{ }^{\text {” }}$ 支配神経の障害等 によって懙粘膜の萎楦が起り，刺激性のガス，過度の舀 内気流等の化学的, 物理的刺激纪よって搝粘膜の肥愿が 起りらることも考えられる。

左右で嗅粘膜所見がこよなっていたものが6例みられ たが，鼻粘膜は同じ原因で忍ずしも両側とも同じ反応を 示すと性らない，左右の舅腔にて解剖的所見がことな ることも多人このような症例が存在するのは当然のこ とと考える。

(7) 嗅覚障害者の治療による咱䊀膜の变化について 腫脹型の嗅粘膜の大部分は治療上ともに次第に分泌液 が減少し，表面の凹凸，色䏱もほぼ正常咱糊膜と同じ状 態に回復した，嗅覚恰查にても暞覚障害は22例中13例が 完全に回復し7 例は軽快した。このここから腫脹型の搝 粘哭は治療に反応しやすく，粘膜の炎症が消退したるの と考えられる. 故に, 腫脹型の暞賞障害者の了後は非常 に良好であると思考している。

分泌型の嗅粘膜は治療とともに分泌液が減少し，嗅覚 积查にても嗅賞障害は10例中７例が完全に回復した。こ の型の嗅粘膜も腫脹型上同栐に治療によく反応し，嗅覚 現象に重要な役割索はたしている唤腺の機能が回復した ものと考える.十なわち, 分泌型の䁵覚障輩者の子後は 良好であると思考している。

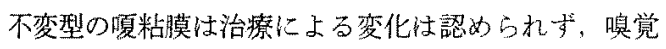
障害が完全に回復したものは17例中 5 例であった。この 型の嗅覚障害の治愍機転については内視鏡所見からは説 明することができなかっった。

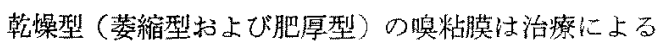
変化は子られず，嗅営障害も完全に回復したものはなか った。.萎縮型のなかにわずかに回復したものが2例欢ら れたがこれについてタ内視鏡所見では変化起認めるこ 上注できなかった。乾燥型は治療にははとんど忘せ ず，予後もまったく不良であった，嗅粘膜の障圊がもっ 上も重篤なものであると考えられる。

以上のよ5に嗅覚障䈍者の嗅粘膜は内視鏡的にいるい ろな病的変化を起こしている毛のが観察され，治療に上 る鮕粘膜の変化む追跡することができた。すなわち睨粘 膜の内視鏡検查により嗅覚障害の的確店䛦断, 治療上了一 後の判定が可能しなったが，まだ完全とはい党す，今後
の研究にむつ分野も多い

\section{結語}

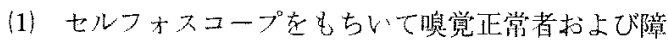

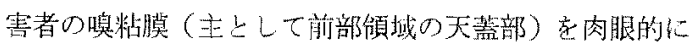
観察し之た。

(2) 嗅党正常者31例について内視鏡検疽を行った，之

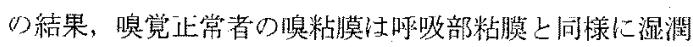
性にと儿でおり，その裴面には榅度の山凸が多数双ら才

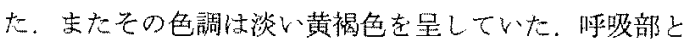
口境界は判然上世子，次第に时吸部战膜に移行してい t:

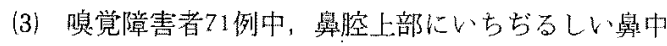

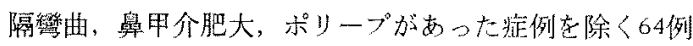
に本検查を行うことができた。

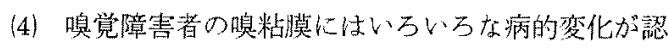
めら机た。これを腫脹型（嗅粘膜の分泌液の增加がみら れ，表面の山凸が消失あるい浅くなり，わずかに荅白

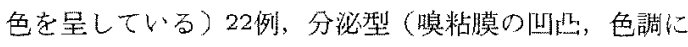
はほとんど変化がみられないが，分泌液が增加してい る）10例，不変型（嗅党正常者の㖵粘膜とほぼ同様の所 見である）17例，乾燥型（嗅粘膜の分泌液が減少ある、 は乾燥し，色調は正常のるのにくらべやや褐色になって いる）9例に分類した。乾燥型をさらに萎維型（嗅粘膜 表面の山凸が媣くなっている）6列と肥厚型(懙粘膜表面 の四凸が消失あるいは浅くなっている)る例とに分けた。 また左在の璂粘膜で病型がことなるもの索6例認かた。

(5) 各病型の原因については腫脹型は唤粘膜の织症,

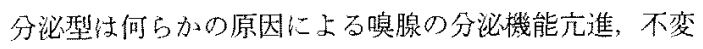

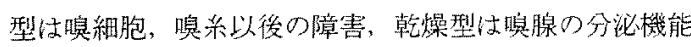

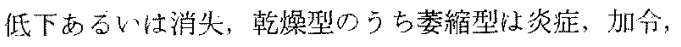
支配神経の障害等, 肥厚型は㷋症, 化学的および物理的 刺激等の原因支推測した。

(6) 腫脹型の筃粘膜は大部分は治療上ともに分泌液が 減少し，尰脹も消失，減退し，色調も正常状態に復し た。この型に属与万搝覚障害者の嗅覚障害杜回復したも

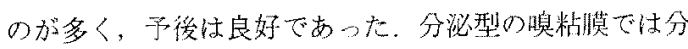
泌液が娍少し，噮覚障害も大部分は回復した。この型に

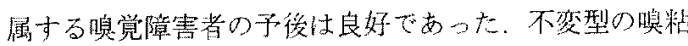
膜には変化汉みられず，予後との相関も内視鏡的には認 められなかった。乾燥型心獣粘膜には变化は認められ

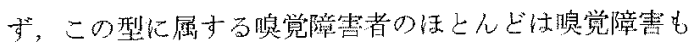
回復・軽快せず。予後住不良であった。

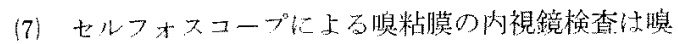


粘膜老肉脚で観察することができ，治潦による变化を追 跞するこ上ができた，またこれにより今までよりも的確

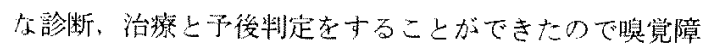
害診断上非常に有効な検查方法であるし信している。

\section{参考文献}

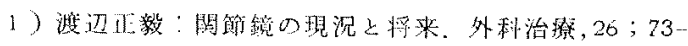
77, 1972.

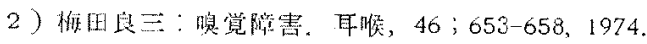

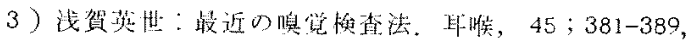
1973.

4) 金于胿之助：日本人休解剖学，第二卷。南山裳，東 京, 1963.

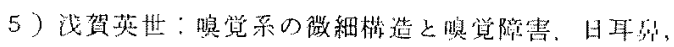
$77 ; 633-635,1974$.

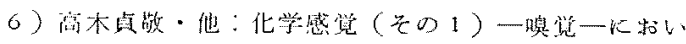

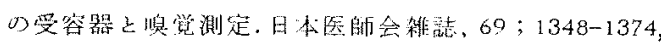
1973.

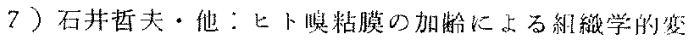

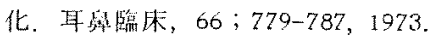

8 ) 高木貞敬: 生理学大系, 第VI巻, 咽喾。1047-1103, 医学書院, 東京, 1967.

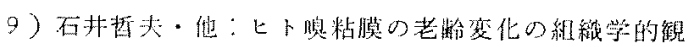

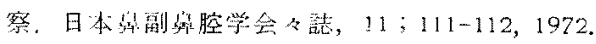

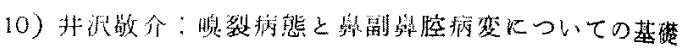

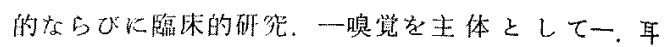
野, $16 ; 133-183,1973$.

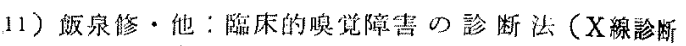

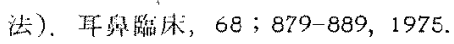

12) G. Morrison: Otolaryngology. W.F. Prior Com. pany, 1960.

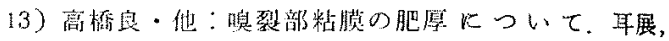
$3 ; 176-182,1960$.

14) Naessen, R.. An enquiry on the morphological characteristics and possible changes with age in the olfactory region of man. Acta Otol, 71;49-62, 1971.

稿を終わると古たり恩印阙本途也教授の御指導ならひ

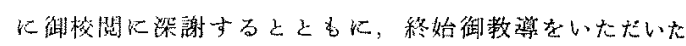
诚贺英性助教授炕感謝与る。

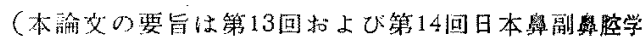
会総会汇和いて笔表した。)

\section{（原稿受付 昭和51.9.20日)}

原著者位所 于814 福阔位陌区大字梅林124-140

舆野 治啓 


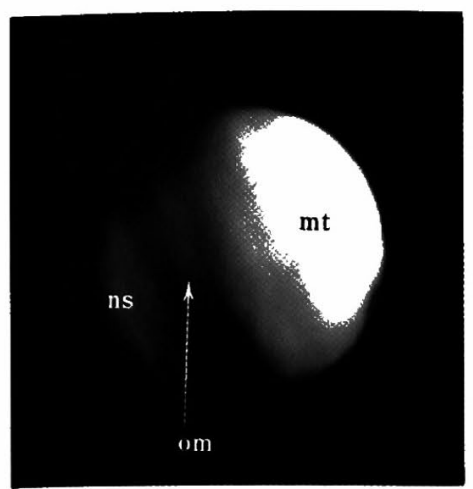

写真 3. 正常嗅粘膜 (左)

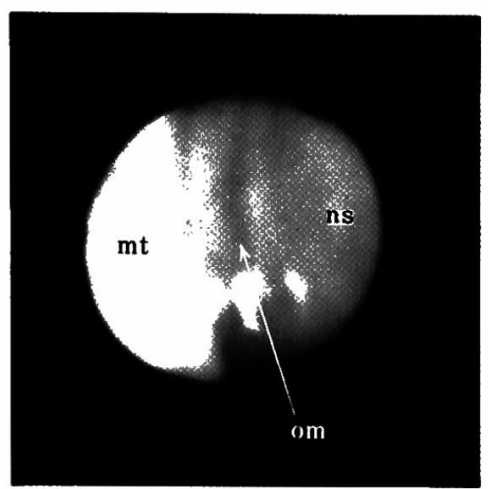

写真 4 腫脹型嗅粘膜（右）

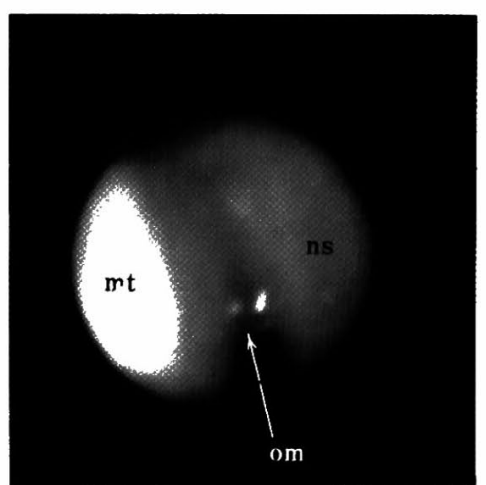

写真 5 分泌型嗅粘膜（右）

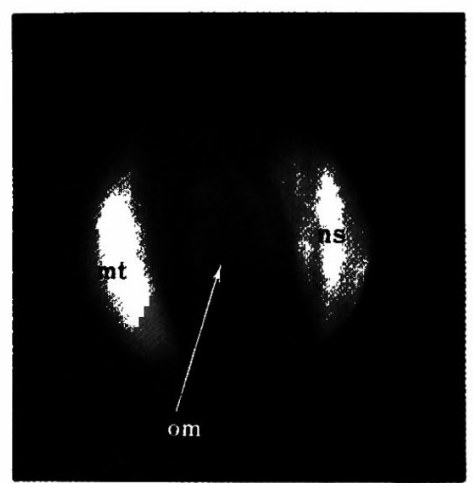

写真 6 . 萎縮型嗅粘膜 (右)

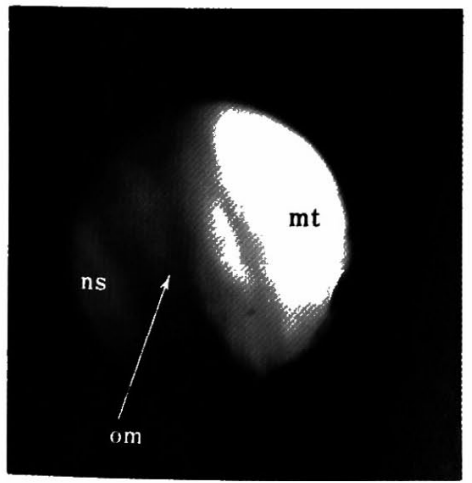

写真 9 . 腫脹型嗅粘膜 (左) 治療後

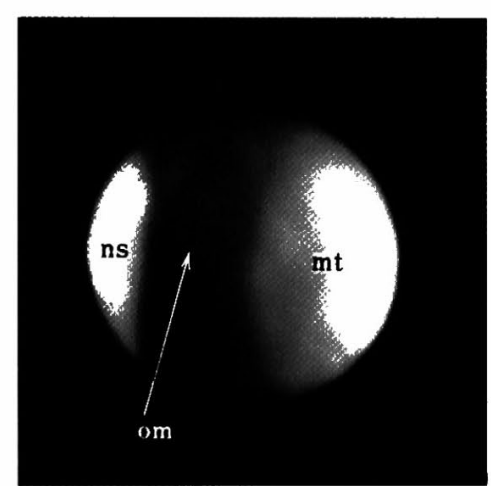

写真 7 肥厚型嗅粘膜 (左)

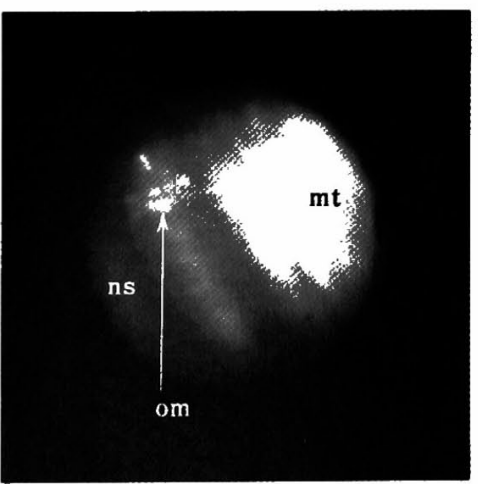

写真 10 . 分泌型嗅粘膜 (左) 治療前

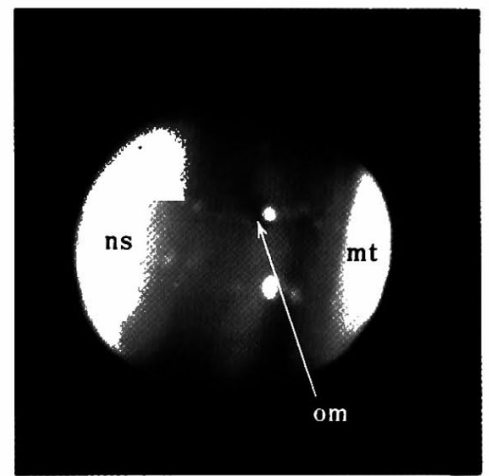

写真 8 . 腫脹型嗅粘膜 (左) 治療前

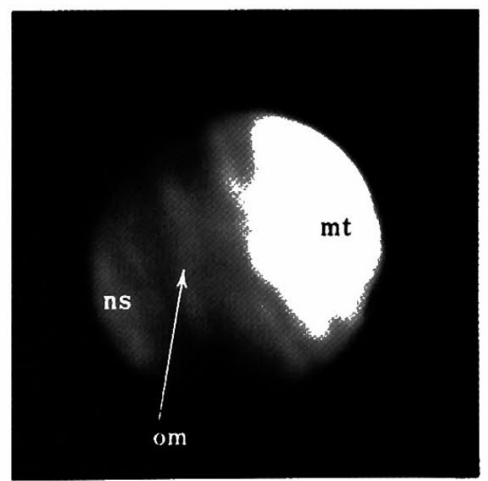

写真11. 分泌型嗅粘膜 (左) 治療後 